\title{
Ecosystem Kongsfjorden: new views after more than a decade of research
}

\author{
Christian Wiencke $^{1} \cdot$ Haakon Hop ${ }^{2,3}$
}

Published online: 19 September 2016

(c) Springer-Verlag Berlin Heidelberg 2016

\section{Introduction}

The Kongsfjorden System in Svalbard is an established reference site for Arctic marine studies that hosts numerous, international, multidisciplinary collaborative science projects. Kongsfjorden $\left(79^{\circ} \mathrm{N}, 12^{\circ} \mathrm{E}\right)$ represents an ideal natural laboratory in the Arctic and functions as a local indicator for climate change. Because of its open connection to Fram Strait, it is directly influenced by variable climate signals in the West Spitsbergen Current (Hop et al. 2006; Walczowski et al. 2012; Wassmann et al. 2015). Advection of transformed Atlantic water into the fjord is important for its seasonal hydrography as well as its biological communities (Cottier et al. 2005, 2007; Hop et al. 2006; Willis et al. 2006, 2008; Dalpadado et al. 2015). In the past, the fjord was regularly covered by sea ice (Gerland and Renner 2007), but because of increased advection of Atlantic water, regular winter ice cover has been rare since 2005/2006 (Cottier et al. 2007). The inner part of the fjord is still rather "Arctic" because it is influenced strongly by glacial runoff from large tidal glaciers (Karner

Christian Wiencke

Christian.Wiencke@awi.de

Haakon Hop

Haakon.Hop@npolar.no

1 Alfred-Wegener-Institute Helmholtz-Center for Polar and Marine Research, Am Handelshafen 12, 27570 Bremerhaven, Germany

2 Norwegian Polar Institute, Fram Centre, 9296 Troms $\varnothing$, Norway

3 Department of Arctic and Marine Biology, Faculty of Biosciences, Fisheries and Economics, UiT The Arctic University of Norway, 9037 Troms $\varnothing$, Norway et al. 2013; Schellenberger et al. 2015). Because of the dual Atlantic/Arctic inputs, the fjord houses pelagic and benthic communities that comprise a mixture of boreal and Arctic flora and fauna, which varies seasonally as well as interannually (Hop et al. 2002, 2012; Walkusz et al. 2009; Voronkov et al. 2013). Kongsfjorden and the adjacent atmospheric Zeppelin Station represent one of the most important environmental monitoring locations in the Arctic.

Scientific data from Kongsfjorden have been sampled for more than 100 years, but it was not until the year 2000 that the first Kongsfjorden Ecosystem Workshop was held at the University Centre in Svalbard; 40 participants attended from France, Germany, Italy, Norway, Poland, Russia, Spain, Sweden and the UK. The results of this workshop were published in two well-recognized reviews focused on the physical environment of KongsfjordenKrossfjorden (Svendsen et al. 2002) and the ecosystem of Kongsfjorden (Hop et al. 2002). Research performed in Kongsfjorden at the Koldewey Station (AWI) during 1991-2003 was presented in a scientific report entitled The coastal ecosystem of Kongsfjorden, Svalbard (Wiencke 2004). Research in Kongsfjorden was further discussed and coordinated during an international workshop in Ny-Ålesund in March 2008, which resulted in a document The Kongsfjorden System-a flagship programme for Ny-Ålesund (Gabrielsen et al. 2009). This flagship programme is currently followed up in Ny-Ålesund seminars, with biannual meetings to exchange scientific results, advancements, ideas and experiences and to increase coordination and collaboration among researchers in Ny-Ålesund.

Within the last decade, much new and important data have been obtained from the growing research community in Ny-Ålesund, now comprising 18 research stations from 11 nations. The new data were summarized and presented 
in a compact manner during a second Kongsfjorden Ecosystem Workshop held on 10-17 March 2014 at the conference facility Hamn i Senja, Skaland, Norway.

This special issue is published in two parts and contains 34 original papers with new results mostly presented during the workshop, with some additional contributions. The papers cover most organism groups and processes relevant to the marine ecosystem from pelagic microbial heterotrophs over zooplankton to benthic micro- and macroalgae, macrozoobenthos, fishes and seabirds. An important section deals with sedimentation and pollutants in sediments. Effects of climate change on biological communities are addressed in several papers. Pertinent comparisons between Kongsfjorden and other fjord systems in Svalbard characterized by different environmental conditions give new insights into expected future changes in Kongsfjorden. Another focus is seasonality of marine organisms and communities, which also includes the winter season. Many studies include new information on biodiversity and trophic interactions.

\section{Part 1}

Global warming affects all regions of the world, but especially the Arctic (Pavlov et al. 2013). Not only the warming itself is problematic, but also the decrease of sea ice cover causing problems for ice-associated species (Barber et al. 2015). On the other hand, the influence of sea ice on the shores declines and opens up potentials for expansion of kelp beds with associated fauna (KrauseJensen and Duarte 2014). However, glaciers are melting and the glacial input of sediments into the fjord changes underwater light conditions and salinity (Hanelt et al. 2001, 2004). Since the end of the Little Ice Age, Svalbard valley glaciers have retreated more than $1 \mathrm{~km}$, and the mass balance of many glaciers around Kongsfjorden is negative (Van Pelt and Kohler 2015). Large areas of glacial rivers have become devoid of ice. This has resulted in the formation of new landforms including vast delta systems, with expansion into the sea. The coastal progradation is up to $5 \mathrm{~m} \mathrm{year}^{-1}$ (Bourriquen et al. 2016). This large amount of sediment supplied in the fjord has an impact on the fjord ecology, especially on the benthic ecosystem, particularly macroalgae and benthic fauna.

Declining sea ice has led to increased human activities in the Arctic and concomitant pressures on the environment. Organotin compounds used in antifouling paints of large seagoing vessels leach into the marine environment and accumulate in sediments and biota. Organotin levels in sediments of Svalbard harbours are still low (below the detection limit up to $14 \mathrm{ng} \mathrm{Sn} \mathrm{g}^{-1} \mathrm{dw}$ sum-butyltin) compared to other Arctic regions with a longer history of shipping (Van Heuvel-Greve et al. 2016). However, contaminant levels in Kongsfjorden should be monitored and mitigation measures put into action if they increase.

Decreasing Arctic sea ice cover and increasing stratification of ocean surface waters make the exposure of pelagic microalgae to high irradiances more likely (Leu et al. 2016). An in situ study determined the effect of high irradiances in general, and ultraviolet radiation (UVR, $280-400 \mathrm{~nm}$ ) in particular, on cell concentrations, fatty acid composition and photoprotective pigments of three diatom species isolated from seawater around Svalbard (Leu et al. 2016). Natural radiation conditions close to the surface reduced growth and polyunsaturated fatty acids (PUFAs) concentrations, but the effects were species specific and the potential of diatoms to acclimate to these conditions over time needs to be further evaluated.

The marine ecosystem of Kongsfjorden experiences large variations in primary productivity due to pronounced seasonal variations in sunlight, glacier melt and sea ice cover. This influences the downward export of biogenic matter (Lalande et al. 2016). The seasonal export fluxes reflected a large phytoplankton bloom grazed upon by zooplankton in May (2012), the melting of glaciers and the intrusion of Atlantic water in August, the end of the glacier melt period in October, and the polar night in January (2013). Warmer Atlantic water and longer glacier melt periods are expected to affect the magnitude and composition of export fluxes in coming years in Kongsfjorden.

Kubiszyn and Wiktor (2015) present a valuable checklist for the dinoflagellate genera Gymnodinium and Gyrodinium. Species of these genera were often included in previous studies as unidentified species. Forty-one taxa were observed of which 23 were identified to the species level.

Increasing temperatures enhance glacier melting, with and concomitant intrusion of freshwater affecting the timing, intensity and composition of the phytoplankton spring bloom in Kongsfjorden; yet, the effects on prokaryotes (bacteria and archaea) are not well understood. A study by Piquet et al. (2015) examined springtime prokaryote communities in both Kongsfjorden and Krossfjorden as a function of hydrographic and phytoplankton variability. An increase in productivity, abundance and proportion of active bacterial cells was observed during the course of spring. Bacteroidetes was the most abundant bacterial group among the assessed taxa in both Kongsfjorden and Krossfjorden, but there were also differences in bacterial and archaeal communities between the fjords.

To get a general conspectus on how Arctic ecosystem will change if the present warming trend persists, several studies were performed in different fjord systems characterized by different hydrographic conditions. Dalpadado et al. (2015) investigated how variations in physical 
characteristics in Kongsfjorden, Isfjorden and Rijpfjorden affect distribution and abundance of euphausiids and pelagic amphipods. Highest abundances of these zooplankton species were recorded in Kongsfjorden, especially at the innermost stations where Arctic and sub-Arctic species dominated. Atlantic species dominated outside Kongsfjorden. Increasing warming trends will likely lead to an expansion of boreal zooplankton into Arctic areas at the expense of large Arctic species, which may further decline. This is expected to affect the structure and energy flow of marine food webs. For example, capelin (Mallotus villosus) and polar cod (Boreogadus saida) feed predominantly on euphausiids and amphipods, respectively, and changes in prey abundance will impact their feeding dynamics.

Another comparative study (Gluchowska et al. 2016) investigated the zooplankton community in Hornsund, Isfjorden and Kongsfjorden in 2006 and 2007, just at the beginning of the warm phase. Hornsund was characterized by cold water from the Arctic, whereas Isfjorden and, especially, Kongsfjorden were influenced by warm Atlantic water. The zooplankton in Hornsund consisted mainly of boreo-Arctic and Arctic species, whereas in Kongsfjorden and Isfjorden high abundances of boreal and ubiquitous species were detected, which indicated the influence of the different hydrographic conditions. Studies of contrasting oceanographic environments can give important insights into how communities will change if the current warming trend persists.

During the last decades, Kongsfjorden has experienced a change in krill species composition due to recent increased advection of Atlantic water masses carrying characteristic boreal as well as subtropical-boreal euphausiids into the ecosystem. A comparison of nutrition and energy storage strategies, stable isotopes, lipid profiles and fatty acid compositions showed remarkable differences among krill species in Kongsfjorden (Huenerlage et al. 2014). The boreal Meganyctiphanes norvegica and subtropical $\mathrm{Ne}$ matoscelis megalops appeared to be more carnivorous with lower lipid contents (29 and $10 \%$, respectively) and a different energy storage pattern (triacylglycerols and polar lipids, respectively) than the arctoboreal Thysanoessa inermis, which consisted of up to $54 \%$ of lipids mainly stored as wax esters $(40 \%)$. These differences may have significant implications for the rapidly changing marine food web of Kongsfjorden, especially for higher trophic levels relying on the nutritional input of animal lipids.

Arctic species of Calanus are critical to energy transfer between higher and lower trophic levels. Their relative abundance and lipid content are influenced by the alternation of cold and warm years. All three species of Calanus were collected during different periods in Kongsfjorden and adjacent shelf during an abnormally warm year (2006) in a study by Mayzaud et al. (2015), which examined lipid composition and fatty acid structure of individual lipid classes in relation to population structure. Composition of fatty acids of wax esters, triglycerides and polar lipids was related to trophic positions of species and varied seasonally. Membrane lipids were the most likely candidate for evaluating adaptive changes in Arctic copepods to hydrothermal regimes.

Seasonal aspects are described in various papers, with focus on how water masses, light and biogeochemistry affect zooplankton communities, particularly organisms sensitive to ocean acidification. Late winter-to-summer changes (April-July) in ocean acidification state, calcium carbonate $\left(\mathrm{CaCO}_{3}\right)$ saturation for aragonite $\left(\Omega_{\mathrm{a}}\right)$ and calcite $\left(\Omega_{\mathrm{c}}\right)$, and biogeochemical properties were investigated in 2013 and 2014 by Fransson et al. (2016). They recorded physical (salinity, temperature) and chemical (carbonate system, nutrients) properties in the water column from the glacier front in the fjord to the West Spitsbergen shelf. The average range of $\Omega_{\mathrm{a}}$ in the upper $50 \mathrm{~m}$ in the fjord in winter was $1.59-1.74$ and in summer $1.65-2.66$. The lowest $\Omega_{\mathrm{a}}$ (1.5) was close to the reported critical threshold for aragonite-forming organisms such as the pteropod Limacina helicina. The inner fjord was influenced by glacial water in summer, which decreased $\Omega_{\mathrm{a}}$ by 0.7 . Biological $\mathrm{CO}_{2}$ consumption, based on a winter-to-summer decrease in nitrate, increased $\Omega_{\mathrm{a}}$ by about the same amount, but the biological effect showed more interannual variability than the effect of freshwater. Changes in the inflow of different water masses and freshwater likely influence ocean acidification state and affect the biological drivers of carbonate chemistry in the fjord.

Lischka and Hagen (2016) described the variation in total mesozooplankton abundance and the occurrence and depth distribution focusing on smaller and larger copepods as well as Limacina helicina. They found pronounced seasonal variations in total zooplankton abundance, with maxima at the beginning of the overwintering period in November (1998). In winter, the zooplankton community was severely impacted by high mortality. Entering the overwintering period with maximum abundances seems to be necessary for successful hibernation and emphasizes the importance of sufficient reproductive success during the previous summer.

One study particularly focused on the winter season in Kongsfjorden. Grenvald et al. (2016) studied community composition and vertical migration of zooplankton during the polar night by use of water samplers and zooplankton net samples supplemented by Acoustic Doppler Current Profiles. A species composition similar to the productive seasons was demonstrated. Classical diel vertical migration (DVM) patterns were not observed between November and mid-January. DVM started when a more 
distinct day-night cycle occurred at the end of January as revealed by acoustics. In February, a classical DVM pattern was also observed in the net samples. Mainly species of the euphausiid genus Thysanoessa, and to a lesser degree chaetognaths and copepods, were responsible for the acoustical migration patterns during the polar night.

More zooplankton seem to be present in Kongsfjorden than previously estimated (Kwasniewski et al. 2003; Hop et al. 2006). Large swarms of zooplankton were observed near the bottom of Kongsfjorden in a survey with remotely operated vehicle (ROV) during the summer and autumn (Hirche et al. 2015). Densities were very high for euphausiids $\left(90,000\right.$ ind. $\left.\mathrm{m}^{-3}\right)$, amphipods $\left(120,000\right.$ ind. $\left.\mathrm{m}^{-3}\right)$, chaetognaths $\left(470,000\right.$ ind. $\left.\mathrm{m}^{-3}\right)$ and Calanus copepods $\left(65,000\right.$ ind. $\left.\mathrm{m}^{-3}\right)$. Neglecting this community may cause severe underestimates of the stock of pelagic zooplankton, especially predatory species, which link secondary production to higher trophic levels. These organisms serve as food for a variety of bottom-bound benthic predators, which may exert a larger pressure than the pelagic predators higher in the water column.

\section{Part 2}

Benthic biodiversity in Kongsfjorden is insufficiently known, and new studies have contributed with important information. Such data represent important baseline information and are useful for a variety of studies, e.g. for a diatom-based monitoring of the sensitive Arctic environment. Al-Handal et al. (2016) studied benthic diatoms from Kongsfjorden. A total number of 67 taxa belonging to 38 genera were encountered, examined by light microscopy, photographed and listed in a catalogue together with their relative abundance. Stachura-Suchoples et al. (2015) studied 26 strains of benthic diatoms from Kongsfjorden by light and electron microscopy and additionally addressed their molecular taxonomy. Four taxa were new to science! The obtained data have been made accessible online and contribute as a first step to a taxonomic reference library for Arctic benthic diatoms.

Global climate changes affect Kongsfjorden in various ways. Stratospheric ozone depletion results in a biologically relevant increase of solar UV-B radiation. The strongest ozone deficit in the Arctic has been observed in 2011 (Manney et al. 2011). Several ecophysiological studies of macroalgae have investigated the reaction of organisms to global climate change, whereas other studies have investigated the reactions of communities. Effects of both physical and biological factors have been considered the papers below.
Lütz et al. (2015) investigated the effect of UV radiation (UVR) on cell ultrastructure and photosynthetic activity in the kelp Alaria esculenta. UVR leads primarily to disruptions and dilations of chloroplast thylakoid membranes. In parallel, photosynthetic activity is inhibited. However, the species was not very strongly stressed by the applied exposure conditions, which points to a high acclimation potential of the species. Roleda (2015) studied the effect of both UVR and different temperatures on spores and juvenile gametophytes of the endemic Arctic kelp Laminaria solidungula. Spores were released from sporophytes collected in late spring to early autumn in deep water (up to $18 \mathrm{~m}$ depth). Meiospore germination and growth of gametophytes were optimal at $12{ }^{\circ} \mathrm{C}$, but photosynthesis was susceptible to UVR. In future ocean warming scenarios, spores and gametophytes are not likely to be affected, but the species will be restricted to deeper waters due to the susceptibility of these stages to UVR.

Ocean acidification modifies the carbon metabolism of seaweeds in various ways. At the first sight, one might think that enhanced supply of $\mathrm{CO}_{2}$ should lead to an elevation of photosynthetic rates. However, this was not the case, as described by Iñiguez et al. (2015), who showed no significant effect of $\mathrm{CO}_{2}$, neither on gross photosynthesis nor on the light saturation parameter $\left(E_{\mathrm{k}}\right.$; Gordillo et al. 2016). Other processes were affected, however, such as respiration, release of dissolved organic carbon (DOC) and accumulation of storage carbohydrates and lipids. As a result, growth was stimulated in three of six species. The growth rate decreased in one species, but was not affected in the other two species (Iñiguez et al. 2015; Gordillo et al. 2016). Elevated temperature combined with elevated $\mathrm{CO}_{2}$ level influenced photosynthetic performance in a speciesspecific way. In $20 \%$ of the cases, a significant interaction of $\mathrm{CO}_{2}$ and temperature was found, and these changes in the physiological performance are expected to propagate to the community level (Gordillo et al. 2016).

What is the effect of elevated temperatures, increased sedimentation and grazing on early developmental stages of kelps? This question was studied by Zacher et al. (2016). Germination of meiospores and formation of juvenile sporophytes of three kelp species from Kongsfjorden were strongly inhibited with increasing sediment cover in all species. Temperature, sedimentation and grazing by the gastropod mollusc Margarites helicinus had variable but strong species-specific interactive effects on these stages. Increasing runoff and elevated temperatures may have the potential to alter the structure of seaweed communities in Kongsfjorden.

A real milestone has been the detection of changes in kelp forest biomass and depth distribution at Hansneset $\left(78^{\circ} 59.1 \mathrm{~N}, 11^{\circ} 57.8 \mathrm{E}\right.$, Blomstrandhalvøya) in Kongsfjorden between 1996 and 1998 (Hop et al. 2012) and 2012 and 
2014 due to global warming (Bartsch et al. 2015). During this time, the peak in kelp biomass shifted upwards in the sublittoral from 5 to $2.5 \mathrm{~m}$ depth. The biomass at this depth was 8.2-fold higher than in the previous investigation, and the lower depth limit of most dominant brown algae had also shifted to shallower depth. The demonstrated changes can be explained as follows: since the winter 2005/2006, the first winter without sea ice cover, ice abrasion decreased allowing for both floral and faunal colonization. Elongation of the open-water period has extended the productive season of seaweeds in Kongsfjorden. The upward shift of the lower depth limit of dominant brown algae is regarded as response to the deterioration of the underwater light regime due to increased water turbidity because of global warming.

As part of the early investigations of macroalgae in Kongsfjorden, most research had focused on one location, Hansneset (Hop et al. 2012), which were also investigated in subsequent studies (Fredriksen et al. 2014; Bartsch et al. 2015). Few studies have included many locations, and only one study by Hop et al. (in review) has surveyed macroalgae on hard-bottom in the entire fjord from the outer reaches of Kongsfjorden-Krossfjorden to the inner glacial bay. This survey was done by scuba-diving from 0 to 30 m depth in 1996 and 1998, as part of a larger study investigating both flora and fauna in Kongsfjorden (Voronkov et al. 2013). Most species recorded in middle fjord at Hansneset were recorded also at other locations in the fjord. While dominant species were typically widely distributed in the fjord, others were distributed either further out or further into the fjord. The biomass of macroalgae was related to depth and distance from the inner glacial bay, and varied with wave exposure and sediment cover. Peaks in biomass varied from 5 to $15 \mathrm{~m}$ at the middle to outer locations in Kongsfjorden, whereas in the inner bay it was at $<5 \mathrm{~m}$. Because of climate warming, with higher sea temperatures and less sea ice, macroalgae have increased in shallow regions of Kongsfjorden (Bartsch et al. 2015), and this is also likely to happen in other areas of the Arctic because of climate warming and less abrasion from sea ice (Krause-Jensen and Duarte 2014).

Macroalgae, in particular kelps, produce a large amount of biomass in Kongsfjorden, which largely is released into the water during the annual cycle. As an example, the brown alga Alaria esculenta loses its blade gradually, $3 \pm 0.8 \%$ of the blade area per day during the autumn (2012), thereby adding to the pool of particulate organic matter (POM) in the fjord (Buchholz and Wiencke 2015). This is interesting because in their preliminary feeding experiment, the mysid Mysis oculata was shown to ingest artificially produced POM (aPOM) from Alaria esculenta, and ingestion of aPOM was also demonstrated in the bivalve Hiatella arctica. The method of generating aPOM from seaweeds is regarded as an important tool for the investigation of the detritus food chain in Kongsfjorden as well as other locations.

During the last decade in Kongsfjorden, the number of ice-free days per year has increased probably due to Arctic warming. As a result, shallow rocky habitats $(2.5-5 \mathrm{~m})$ are less affected by ice scouring, thereby opening new space for colonization by benthic fauna. Changes observed in the kelp forest at Hansneset, Kongsfjorden (Bartsch et al. 2015), were accompanied by similar changes of the macrozoobenthos in the seaweed forest at the same site (Paar et al. 2015). In comparison with 1996-1998 (Voronkov et al. 2013), macrozoobenthic depth distribution was inversed in 2012-2013 due to a tenfold increase in biomass and secondary production in the uppermost sublittoral (Paar et al. 2015). Macrozoobenthic production constitutes an important link between primary production and higher trophic levels. Secondary production was low, however, compared to primary production of macroalgae, pointing to a strong export of most of the algal production, as fresh material or detritus, to other areas of the fjord.

Arctic hard-bottom locations are habitats for a variety of benthic organisms, which have been described by species occurrence, abundance or biomass (Voronkov et al. 2013). However, only few studies, such as Voronkov et al. (2016), have included descriptions of communities on such locations in the Arctic, whereas this has been frequently done for soft-bottom communities (e.g. Wlodarska-Kowalczuk et al. 1998; Kedra et al. 2011). Thus, the focus of the study by Voronkov et al. (2016) was to determine a limited number of characteristic zoobenthic communities that occupy Arctic shallow subtidal habitats (0-30 m depth) on hard-bottom locations in Kongsfjorden. Seven communities were identified after considering species dominance, similarity between species associations and the potential role of conspicuous species in the communities. For establishment of communities, barnacles (Balanus balanus) and branched bryozoans were considered particularly important, whereas macroalgae were of less importance for identification of communities and distributional patterns of zoobenthos.

Arctic macrozoobenthic, soft-sediment communities are considerably disturbed by calving icebergs and sediments from tidal glaciers. Nowak et al. (2016) described the primary succession of macrozoobenthic communities after disturbances at $20 \mathrm{~m}$ depth near Brandal, Kongsfjorden. A shift from pioneering species (e.g. Cumacea: Lamprops fuscatus) towards more specialized taxa as well as from surface detritivores towards subsurface detritivores was observed. After 3 years, the community had still not fully matured, which demonstrated the long-lasting effects of severe disturbances on Arctic macrozoobenthic communities. However, environmental changes, such as rising 
temperatures coupled with enhanced food availability due to an increasing frequency of sea ice-free days per year, may have a stronger effect on succession than exposure time of disturbance.

Wlodarska-Kowalczuk et al. (2016) investigated relations between the marked seasonality in pelagic productivity and phytodetritus fluxes to the sea bottom on taxonomic composition and standing stocks of benthic communities. They detected no consistent differences in meio- and macrofaunal density, diversity or composition during the year, although possible responses to spring food supply in meiofaunal reproduction were observed in Nematoda, Harpacticoida and macrobenthic Crustacea. They concluded that the resilience of the benthic community to marked seasonality in pelagic phytodetritus fluxes may be related to organic matter reserves in sediments, inclusion of macroalgal carbon into the diet (see also Buchholz and Wiencke 2015) and employment of lecitotrophic larva or direct development by polar benthos.

The effects of biotic disturbances, like seaweed whiplash, on the diversity of benthic communities are well documented for temperate coastal systems, yet missing for Arctic benthos (Petrowski et al. 2015a). In Arctic softbottom habitats, kelp thalli occur either continuously (e.g. trapped by sediment) or sporadically (by drifting on the sediment) after detachment from rocky shores. To explore whether a kelp thallus can disturb the structure and diversity of a coastal Arctic soft-bottom assemblage, Petrowski et al. (2015a) fixed a single thallus of the kelp Saccharina latissima onto sediment and recorded 45 associated animal taxa taken from plots with different seaweed treatments. They concluded that the presence and movements of a single kelp thallus could promote small-scale patchiness in near-shore soft-bottom assemblage structure and diversity, which exemplifies a significant connection between rocky and sedimentary coastal habitats.

Biotic factors such as bioturbation and predation affect abundance and species composition of marine soft-bottom communities, but their impacts have rarely been investigated in Arctic coastal systems. In a manipulative field experiment, Petrowski et al. (2015b) excluded the bioturbating lugworm Arenicola marina and predacious consumers from a sedimentary nearshore area in Kongsfjorden for 70 days to explore their role in structuring the benthic community. The removal of $A$. marina caused an increase in average species number by $25 \%$, a doubling increase in the average number of individuals and an increase in dry mass of benthic organisms by, on average, $73 \%$ in comparison with untreated areas. Community composition was significantly modified by lugworm exclusion resulting in higher average densities of species such as the cumacean Lamprops fuscatus, the polychaete worms Euchone analis and Pygospio cf. elegans, the bivalve Crenella decussata and the amphipod Crassicorophium crassicorne. Consumer exclusion, by contrast, showed no effects on the response variables. Present levels of bioturbation and predation by macroepibenthic consumers might change in a predicted warmer Arctic with assumed higher predator abundances and a northward expansion of boreal consumers.

Climate change is expected to cause structural changes in Arctic ecosystems, including extinction of local species and species invasions. A lack of basic biological data about the Arctic shallow-water fish community makes it hard to assess whether these communities will change or not. Thus, baseline studies in combination with future reassessments are needed to establish basic knowledge about the change of these communities. A study by Brand and Fischer (2016) provided a quantitative first-time description of the shallow-water fish community in Kongsfjorden. Samples included 12 fish species, mainly shorthorn sculpin (Myoxocephalus scorpius) (74.9\%), Atlantic cod (Gadus morhиа) (17.2\%) and Arctic staghorn sculpin (Gymnocanthus tricuspis) $(3.8 \%)$. Both macroalgal abundance and the hydrographic regime affected the biodiversity of fishes in the fjord.

The Greenland shark (Somniosus microcephalus) is an important, large predator in the Arctic, including Kongsfjorden. Studies of this species were summarized in a review paper by Lydersen et al. (2016). A total of 76 sharks have been caught on baited lines during the summers of 2008 and 2009 in Kongsfjorden. All of these animals, including the largest shark, a female weighing $700 \mathrm{~kg}$, were sexually immature. Approximately half of the gastrointestinal tracts examined contained seal tissue $(42.3 \%)$, and some also contained minke whale (Balaenoptera acutorostrata) tissue (18.2\%). Atlantic cod, Atlantic wolffish (Anarhichas lupus) and haddock (Melanogrammus aeglefinus) were the dominant fish species consumed by the sharks. Many of the fishes were swallowed whole, including an Atlantic wolffish weighing $8.6 \mathrm{~kg}$. Satellite pop-up tags deployed on 20 of the sharks showed that they travelled in the water column from the surface to depths greater than $1500 \mathrm{~m}$, encountering temperatures from -1.5 to $7.4{ }^{\circ} \mathrm{C}$. Accelerometers deployed on six of the sharks showed that they swim extremely slowly, with average speeds of $0.34 \mathrm{~m} \mathrm{~s}^{-1}$ and burst speeds of only twice this value. Greenland sharks are not only scavengers, but also active predators of both fish and mammalian prey. However, given the slow swim speed of these sharks, Lydersen et al. (2016) suggested that the only way they could successfully capture a healthy seal is via cryptically approaching seals that are asleep in the water.

Another aspect of seasonality is the migration of birds from Kongsfjorden to the overwintering areas, which was studied by Hanssen et al. (2016) exemplifying the migration strategies of common eiders (Somateria mollissima) 
for the first time. All tracked birds wintered either in Iceland or in North Norway and left Svalbard between late August and late December. Spring migration took place from late March to late May. Other studies have shown that the breeding populations, especially in Norway (Fauchald et al. 2015) but also in Iceland (Jónnsson et al. 2013), are decreasing. The authors conclude that the winter survival of Svalbard breeding birds may be at a risk if these declines reflect deterioration of feeding habitat quality or other environmental conditions during winter. Thus, a bilateral conservation management should be considered for this important Arctic breeding population of common eider.

Finally, Greenacre (in review) explains basic statistical concepts and shows ways of visualizing summaries of variables in ecological research. The function of logarithmic transformation of positive data and its implications for the demonstration of results in multiplicative rather than in additive form are described. Furthermore, ordination plots derived from multivariate analyses, such as principal component analysis and canonical correspondence analysis, are discussed and improvements suggested. Some data sets were taken from papers of the Kongsfjorden Special Issue as examples. Clearly, this is a valuable contribution not only for polar researchers, but also for experimental ecologists worldwide.

Acknowledgments The Kongsfjorden workshop with 50 presentations from 60 national and international participants made it possible to assemble this Special Issue of Polar Biology published in two parts. We are sincerely grateful for funding from the Norwegian Polar Institute, the Research Council of Norway, Svalbard Science Forum, Havet og kysten (Project No. 234347), Fram Centre Flagship, Fjord\&Kyst (Project no. 2014-8), Alfred Wegener Institute, Helmholtz Centre for Polar and Marine Research, Kings Bay AS and DFGSPP Antarctic Research, which made it possible to host this workshop at Hamn i Senja in 2014. We thank all participants in this workshop and contributing authors, who made these volumes possible. We thank Prof. Michael Greenacre for his combined musical-statistical performances during the workshop and for accepting our challenge to contribute a paper on how to report and visualize data. $\mathrm{He}$ is acknowledged for edits of statistics in all contributed papers. Finally, we wish to thank the Centre for Ice, Climate and Ecosystems (ICE) at NPI, which supported our workshop initiative in the early critical phase of this project. We thrust that these volumes will become a milestone for future work in Kongsfjorden for years to come and will strengthen the ongoing Ny-Ålesund Research Flagship Programme, where the Kongsfjorden System is one of the four flagships (http:// nysmac.npolar.no/research/flagships/kongsfjorden.html).

\section{References}

Al-Handal AY, Fricke A, Wulff A (2016) Observations on diatoms inhabiting natural and artificial substrates in Kongsfjorden, Svalbard, the Arctic. Polar Biol. doi:10.1007/s00300-016-1998-7

Barber DG, Hop H, Mundy CJ, Else B, Dmitrenko IA, Tremblay J-E, Ehn JK, Assmy P, Daase M, Candlish LM, Rysgaard S (2015) Selected physical, biological and biogeochemical implications of a rapidly changing Arctic Marginal Ice Zone. Progr Oceanogr 139:122-150

Bartsch I, Paar M, Fredriksen S, Schwanitz M, Daniel C, Hop H, Wiencke C (2015) Changes in kelp forest biomass and depth distribution in Kongsfjorden, Svalbard, between 1996-1998 and 2012-2014 reflect Arctic warming. Polar Biol. doi:10.1007/ s00300-015-1870-1

Bourriquen M, Baltzer A, Mercier D, Fournier J, Pérez L, Haquin S, Bernard E, Jensen M (2016) Coastal evolution and sedimentary mobility of Brøgger Peninsula, northwest Spitsbergen. Polar Biol. doi:10.1007/s00300-016-1930-1

Brand M, Fischer P (2016) Species composition and abundances of the shallow-water fish community of Kongsfjorden, Svalbard. Polar Biol. doi:10.1007/s00300-016-2022-y

Buchholz CM, Wiencke C (2015) Working on a baseline for the Kongsfjorden food web: production and properties of macroalgal particulate organic matter (POM). Polar Biol. doi:10.1007/ s00300-015-1828-3

Cottier F, Tverberg V, Inall M, Svendsen H, Nilsen F, Griffiths C (2005) Water mass modification in an Arctic fjord through crossshelf exchange: the seasonal hydrography of Kongsfjorden, Svalbard. J Geophys Res. doi:10.1029/2004JC002757

Cottier FR, Nilsen F, Inall ME, Gerland S, Tverberg V, Svendsen H (2007) Wintertime warming of an Arctic shelf in response to large-scale atmospheric circulation. Geophys Res Lett 34:L10607. doi:10.1029/2007GL029948

Dalpadado P, Hop H, Rønning J, Pavlov V, Sperfeld E, Buchholz F, Rey A, Wold A (2015) Distribution and abundance of euphausiids and pelagic amphipods in Kongsfjorden, Isfjorden and Rijpfjorden (Svalbard) and changes in their relative importance as key prey in a warming marine ecosystem. Polar Biol. doi:10. 1007/s00300-015-1874-x

Fauchald P, Anker-Nilssen T, Barrett RT, Bustnes JO, Bårdsen BJ, Christensen-Dalsgaard S, Descamps S, Engen S, Erikstad KE, Hanssen SA, Lorentsen S-H, Moe B, Reiertsen TK, Strøm H, Systad GH (2015) The status and trends of seabirds breeding in Norway and Svalbard-NINA Report 1151, Troms $\varnothing$

Fransson A, Chierici M, Hop H, Findlay HS, Kristiansen S, Wold A (2016) Late winter-to-summer change in ocean acidification state in Kongsfjorden, with implications for calcifying organisms. Polar Biol. doi:10.1007/s00300-016-1955-5

Fredriksen S, Bartsch I, Wiencke C (2014) New additions to the benthic marine flora of Kongsfjorden, western Svalbard, and comparison between 1996/1998 and 2012/2013. Bot Mar 57:203-216

Gabrielsen GW, Hop H, Hübner C, Kallenborn R, Weslawski JM, Wiencke C (eds) (2009) The Kongsfjorden system-a flagship programme for Ny-Ålesund. A concluding document from Workshop 28-31 March., 2008. Brief Report Series no. 11, Norwegian Polar Institute, Troms $\varnothing$

Gerland S, Renner AHH (2007) Sea-ice mass balance monitoring in an Arctic fjord. Ann Glaciol 46:435-442

Gluchowska M, Kwasnieweski S, Prominska A, Olszeweska A, Goszczko I, Falk-Petersen S, Hop H, Weslawski JM (2016) Zooplankton in Svalbard fjords on the Atlantic-Arctic boundary. Polar Biol. doi:10.1007/s00300-016-1991-1

Gordillo FJL, Carmona R, Viñegla B, Wiencke C, Jiménez C (2016) Effects of simultaneous increase in temperature and ocean acidification on biochemical composition and photosynthetic performance of common macroalgae from Kongsfjorden (Svalbard). Polar Biol. doi:10.1007/s00300-016-1897-y

Greenacre MJ (in review) Data reporting and visualization in ecology. Polar Biol

Grenvald JC, Callesen TA, Daase M, Hobbs L, Darnis G, Renaud PE, Cottier F, Nielsen TG, Berge J (2016) Plankton community 
composition and vertical migration during polar night in Kongsfjorden. Polar Biol. doi:10.1007/s00300-016-2015-x

Hanelt D, Bischof K, Wiencke C (2004) The radiation, temperature and salinity regime in Kongsfjorden. Ber Polarforsch Meeresforsch 492:14-25

Hanelt D, Tüg H, Bischof K, Gross C, Lippert H, Sawall T, Wiencke C (2001) Light regime in an Arctic fjord: a study related to stratospheric ozone depletion as a basis for determination of UV effects on algal growth. Mar Biol 138:649-658

Hanssen SA, Gabrielsen GW, Bustnes JO, Bråthen Skottene E, Fenstad AA, Strøm H, Bakken V, Phillips RA, Moe B (2016) Migration strategies of common eiders from Svalbard: implications for bilateral conservation management. Polar Biol. doi:10. 1007/s00300-016-1908-z

Hirche H-J, Laudien J, Buchholz F (2015) Near-bottom zooplankton aggregations in Kongsfjorden: implications for pelago-benthic coupling. Polar Biol. doi:10.1007/s00300-015-1799-4

Hop H, Falk-Petersen S, Svendsen H, Kwasniewski S, Pavlov V, Pavlova O, Søreide JE (2006) Physical and biological characteristics of the pelagic system across Fram Strait to Kongsfjorden. Progr Oceanogr 71:182-231

Hop H, Kovaltchouk NA Wiencke, C (in review) Distribution of macroalgae in Kongsfjorden, Svalbard. Polar Biol

Hop H, Pearson T, Hegseth EN, Kovacs KM, Wiencke C, Kwasniewski S, Eiane K, Mehlum F, Gulliksen B, WlodarskaKowalczuk M, Lydersen C, Weslawski JM, Cochrane S, Gabrielsen GW, Leakey RJG, Lønne OJ, Zajaczkowski M, Falk-Petersen S, Kendall M, Wängberg S-A, Bischof K, Voronkov AY, Kovaltchouk NA, Wiktor J, Poltermann M, di Prisco G, Papucci C, Gerland S (2002) The marine ecosystem of Kongsfjorden, Svalbard. Polar Res 21:167-208

Hop H, Wiencke C, Vögele B, Kovaltchouk NA (2012) Species composition, zonation, and biomass of marine benthic macroalgae in Kongsfjorden, Svalbard. Bot Mar 55:399-414

Huenerlage K, Graeve M, Buchholz F (2014) Lipid composition and trophic relationships of krill species in a high Arctic fjord. Polar Biol. doi:10.1007/s00300-014-1607-6

Iñiguez C, Carmona R, Lorenzo MR, Niell FX, Wiencke C, Gordillo FJL (2015) Increased $\mathrm{CO}_{2}$ modifies the carbon balance and the photosynthetic yield of two common Arctic brown seaweeds: Desmarestia aculeata and Alaria esculenta. Polar Biol. doi:10. 1007/s00300-015-1724-x

Jónnsson JE, Gardarsson A, Gill JA, Pétursdóttir UK, Petersen A, Gunnarsson TG (2013) Relationships between long-term demography and weather in a sub-Arctic population of common eider. PLoS One 8(6):e67093. doi:10.1371/journal.pone.0067093

Karner F, Obleitner F, Krismer T, Kohler J, Greuell W (2013) A decade of energy and mass balance investigations on the glacier Kongsvegen, Svalbard. J Geophys Res Atm 118:3986-4000

Kedra M, Legezynska J, Walkusz W (2011) Shallow winter and summer macrofauna in high Arctic fjord $\left(79^{\circ} \mathrm{N}\right.$, Spitsbergen). Mar Biodiv 41:425-439

Krause-Jensen D, Duarte C (2014) Expansion of vegetated coastal ecosystems in the future Arctic. Front Mar Sci. doi:10.3389/ fmars.2014.00077

Kubiszyn AM, Wiktor JM (2015) The Gymnodinium and Gyrodinium (Dinoflagellata: Gymnodiniaceae) of the West Spitsbergen waters (1999-2010): biodiversity and morphological description of unidentified species. Polar Biol. doi:10.1007/s00300-015$1764-2$

Kwasniewski S, Hop H, Falk-Petersen S, Pedersen G (2003) Distribution of Calanus species in Kongsfjorden, a glacial fjord in Svalbard. J Plankton Res 25:1-20

Lalande C, Moriceau B, Leynaert A, Morata N (2016) Spatial and temporal variability in export fluxes of biogenic matter in Kongsfjorden. Polar Biol. doi:10.1007/s00300-016-1903-4
Leu E, Graeve M, Wulff A (2016) A (too bright) future? Arctic diatoms under radiation stress. Polar Biol. doi:10.1007/s00300016-2003-1

Lischka S, Hagen W (2016) Seasonal dynamics of mesozooplankton in the Arctic Kongsfjord (Svalbard) during year-round observations from August 1998 to July 1999. Polar Biol. doi:10.1007/ s00300-016-2005-z

Lütz C, di Piazza L, Fredersdorf J, Bischof K (2015) The effect of ultraviolet radiation on cellular ultrastructure and photosystem II quantum yield of Alaria esculenta (L.) Greville from Spitsbergen (Norway). Polar Biol. doi:10.1007/s00300-015-1659-2

Lydersen C, Fish AT, Kovacs KM (2016) A review of Greenland shark (Somniosus microcephalus) studies in the Kongsfjorden area, Svalbard Norway. Polar Biol. doi:10.1007/s00300-0161949-3

Manney GL, Santee ML, Rex M, Livesey NJ, Pitts MC, Veefkind P, Nash ER, Wohltmann I, Lehmann R, Froidevaux L, Poole LR, Schoeberl MR, Haffner DP, Davies J, Dorokhov V, Gernandt H, Johnson B, Kivi R, Kyrö E, Larsen N, Levelt PF, Makshtas A, McElroy CT, Nakajima H, Parrondo MC, Tarasick DW, von der Gathen P, Walker KA, Zinoviev NS (2011) Unprecedented Arctic ozone loss in 2011. Nature 478:469-475

Mayzaud P, Falk-Petersen S, Noyon M, Wold A, Boutoute M (2015) Lipid composition of the three co-existing Calanus species in the Arctic: impact of season, location and environment. Polar Biol. doi:10.1007/s00300-015-1725-9

Nowak CA, Laudien J, Sahade R (2016) Rising temperatures and seaice free winters affect the succession of Arctic macrozoobenthic soft-sediment communities (Kongsfjorden, Svalbard). Polar Biol. doi:10.1007/s00300-016-1995-x

Paar M, Voronkov A, Hop H, Brey T, Bartsch I, Schwanitz M, Wiencke C, Lebreton B, Asmus R, Asmus H (2015) Temporal shift in biomass and production of macrozoobenthos in the macroalgal belt at Hansneset, Kongsfjorden, after 15 years. Polar Biol. doi:10.1007/s00300-015-1760-6

Pavlov AK, Tverberg V, Ivanov BV, Nilsen F, Falk-Petersen S, Granskog MA (2013) Warming of Atlantic Water in two west Spitsbergen fjords over the last century (1912-2009). Polar Res 32:11206. doi:10.3402/polar.v32i0

Petrowski S, Molis M, Bender A, Buschbaum C (2015a) Disturbance effects of kelp thalli on structure and diversity of a coastal Arctic marine soft-bottom assemblage. Polar Biol. doi:10.1007/s00300015-1714-z

Petrowski S, Molis M, Schachtl K, Buschbaum C (2015b) Do bioturbation and consumption affect coastal Arctic marine softbottom communities? Polar Biol. doi:10.1007/s00300-015-16547

Piquet AM-T, Maat DS, Confurius-Guns V, Sintes E, Herndl GJ, van de Poll WH, Wiencke C, Buma AGJ, Bolhuis H (2015) Springtime dynamics, productivity and activity of prokaryotes in two Arctic fjords. Polar Biol. doi:10.1007/s00300-015-1866-x

Roleda MY (2015) Stress physiology and reproductive phenology of Arctic endemic kelp Laminaria solidungula J. Agardh. Polar Biol. doi:10.1007/s00300-015-1813-x

Schellenberger T, Dunse T, Kaab A, Kohler J, Reijmer CH (2015) Surface speed and frontal ablation of Kronebreen and Kongsbreen, from SAR offset tracking. Cryosphere 9:2339-2355

Stachura-Suchoples K, Enke N, Schlie C, Schaub I, Karsten U, Jahn R (2015) Contribution towards a morphological and molecular taxonomic reference library of benthic marine diatoms from two Arctic fjords on Svalbard (Norway). Polar Biol. doi:10.1007/ s00300-015-1683-2

Svendsen H, Beszczynska-Möller A, Hagen JO, Lefauconnier B, Tverberg V, Gerland S, Ørbæk JB, Bischof K, Papucci C, Zajaczkowski M, Azzolini R, Bruland O, Wiencke C, Winther J-G, Dallmann W (2002) The physical environment of 
Kongsfjorden-Krossfjorden, an Arctic fjord system in Svalbard. Polar Res 21:133-166

Van Heuvel-Greve M, Szczybelski AS, van den Brink NW, Kotterman MJJ, Kwadijk CJAF, Evenset A, Murk AJ (2016) Low organotin contamination of harbour sediment in Svalbard. Polar Biol. doi:10.1007/s00300-016-1907-0

Van Pelt W, Kohler J (2015) Modelling the long-term mass balance and firn evolution of glaciers around Kongsfjorden. J Glaciol 61:731-744

Voronkov A, Hop H, Gulliksen B (2013) Diversity of hard-bottom fauna relative to environmental gradients in Kongsfjorden, Svalbard. Polar Res 32:11208. doi:10.3402/polar.v32i0.11208

Voronkov A, Hop H, Gulliksen B (2016) Zoobenthic communities on hard-bottom habitats in Kongsfjorden, Svalbard. Polar Biol. doi:10.1007/s00300-016-1935-9

Walczowski W, Piechura J, Goszczko I, Wieczorek P (2012) Changes in Atlantic water properties: an important factor in the European Arctic marine climate. ICES J Mar Sci 69:864-869

Walkusz W, Kwasniewski S, Falk-Petersen S, Hop H, Tverberg V, Wieczorek P, Weslawski JM (2009) Seasonal and spatial changes in zooplankton composition in the glacially influenced Kongsfjorden, Svalbard. Polar Res 28:254-281

Wassmann P, Kosobokova KN, Slagstad D, Drinkwater KF, Hopcroft RR, Moore SE, Ellingsen I, Nelson RJ, Carmack E, Popova E,
Berge J (2015) The contiguos domains of Arctic Ocean advection: trails of life and death. Progr Oceanogr 139:42-65

Wiencke C (2004) The coastal ecosystem of Kongsfjorden, Svalbard. Synopsis of biological research performed at the KoldeweyStation in the years 1991-2003. Ber Polarforsch Meeresforsch 492:1-244

Willis KJ, Cottier FR, Kwasniewski S (2008) Impact of warm water advection on the winter zooplankton community in an Arctic fjord. Polar Biol 31:475-481

Willis KJ, Cottier FR, Kwasniewski S, Wold A, Falk-Petersen S (2006) The influence of advection on zooplankton community composition in an Arctic fjord (Kongsfjorden, Svalbard). J Mar Syst 61:39-54

Wlodarska-Kowalczuk M, Górska B, Deja K, Morata N (2016) Do benthic meiofaunal and macrofaunal communities respond to seasonality in pelagial processes in an Arctic fjord (Kongsfjorden, Spitsbergen)? Polar Biol. doi:10.1007/s00300-016-1982-2

Wlodarska-Kowalczuk M, Weslawski JM, Kotwicki L (1998) Spitsbergen glacial bays macrobenthos-a comparative study. Polar Biol 20:66-73

Zacher K, Bernard M, Bartsch I, Wiencke C (2016) Survival of early life history stages of Arctic kelps (Kongsfjorden, Svalbard) under multifactorial global change scenarios. Polar Biol. doi:10. 1007/s00300-016-1906-1 